\title{
The vertical cities: reality or utopia of the future
}

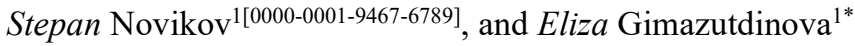 \\ ${ }^{1}$ Kazan State University of Architecture and Engineering, 420043 Kazan, Russia
}

\begin{abstract}
Growth of population affects the increase in demand for development of new areas. The article discusses current problems and trends in the development of vertical cities of the future. The last decade has seen the consolidation of the urban environment and the transition of urban planning from horizontal to vertical. The structure of future vertical cities minimizes land use and contributes to solving environmental problems and de-urbanization. The authors analyze the origin of «utopia» word and its meaning in the concepts of utopian cities since ancient times. The formation of a comfortable vertical city is a utopia aimed at turning it into the reality of the future. A general analysis of space-planning and architectural solutions of modern concepts helped to formulate the basic principles of creating a vertical city. The identified criteria of the architectural space will allow humanity to live in a comfortable environment, including the period of forced critical conditions. During the research, we presented a hypothesis of the emergence of vertical cities in the world and in Russia. The study can become the basis for forecasting the processes of urbanization and deurbanization, also as a concept creation for the development of a sustainable model of the future vertical city.
\end{abstract}

Keywords. Vertical city, utopia, sustainable urbanism, architecture, overpopulation, urban planning structure.

\section{Introduction}

The problem of overpopulation and increasing population density in cities is particularly relevant in the last decade. According to the UN, there will be about 10 billion people on the planet by 2050. Large cities need to adapt to the rapid pace of land development. Nature is losing the war against urbanization, this affects climate change, the purity of air, water resources, soils and, in general, the violation of the ecological state of the environment [1]. The psychological aggravation of all spheres of human life led to isolation, to the limitation of life processes, to the desire to create a more reliable and comfortable living environment around oneself in the 2020 pandemic [2]. The restructuring of the priorities of mass services is taking place on new values: safety, longevity, comfort, ecological environment, culture, reduction of global risks and active visual perception of the environment by humans. Massive development of «consumer» planning creates uncomfortable, unsafe and unhealthy cities.

The projects of architects and researchers have always contained ideas for the development and reclamation of new lands, work with extreme climatic zones and relief, with the elements of earth, water and air. Interest in architectural fantasies and concepts of future cities did not

\footnotetext{
*Corresponding author: egimazutdinova@mail.ru
} 
fade away, it was a constant catalyst for the creation of a limitless number of ideas for everyday life in the urban space. Architectural concepts and research on future cities were in the works of Charles Fourier, Ebenezer Howard, Le Corbusier, Yona Friedman, Buckminster Fuller, Frank Lloyd Wright. In the $21^{\text {st }}$ century, Luca Curci Architects is actively developing projects for the vertical arrangement of cities. Vincent Callebaut puts forward many concepts for future cities with an ecological aspect. John Wardle Architects and Stefano Boscuitti showcase the Multiplicity project. This is the vertical development of the existing city by the end of the $21 \mathrm{st}$ century. The eVolo 2021 Skyscraper Competition, The SKYHIVE 2020 Skyscraper and various competitions for creating master plans for new cities are the driving force behind the creation of future vertical cities and solving global problems.

The modern world is not like the one that past generations dreamed of. After industrialization, the place was taken by urbanization, megalopolises were actively built. The space-planning structure of cities developed horizontally, the height of buildings and the number of floors increased [3].

Utopia appears in all concepts and forecasts of the future world that will make our life more comfortable [4-6]. These are often idealized projects that contain the fears and hopes of the society. Many researchers and architects were involved in the development of vertical cities. Vertical construction is a reality. Future vertical cities are utopia. What is the difference between isolated skyscrapers and vertical cities?

The concept of a vertical city means that it is a set of vertical buildings with a developed infrastructure $[7,8]$. It is a whole ecosystem in the air environment, which is many times larger than a building spot on earth. Each person must have their own living cell, adaptable and safe in a vertical city [9-11]. Lack of leisure drives a person to a vicious circle between work and home; therefore, it is important to create a compact planning structure with public places. As a result, the formation of the architecture of the future vertical city [12-14] and conceptual ideas for residential complexes should contribute to solving environmental problems and de-urbanization. Projects should combine a model of high sustainability and high-quality living standards of the population [15]. Active development of innovative technologies in building materials $[16,17]$, design features of high-rise buildings $[18,19]$, in the field of landscaping facades $[20,21]$ contributes to the expansion and systematization of the vision of future vertical cities [22].

\section{Materials and methods}

The materials of this study are based on theoretical works and projects of architects, philosophers, and researchers. Since ancient times, thinkers and philosophers have been trying to envision an ideal life. Urban planning and architecture were also a base for such concepts. Babel Tower embodies the connection with the Almighty, the imagined world of Atlantis - known from Plato's dialogues - is the eighth tetralogy, telling about the problems of an ideal city with centric planning schemes and defined outskirts. Hippodamus of Miletus developed an urban planning principle which was based on rectangular residential blocks and a defined grid of streets. This principle was named grid plan and has been widely used as a base for numerous cities. Vedutas of the mid $-15^{\text {th }}$ century are an embodiment of the views about ideal cities. In 1516, Thomas More first defined the concept of utopia. According to More, Utopia is a country that existed in the past or exists now. This country is located on an island and the humanity has not reached it yet, even though it is theoretically possible. In his work, Thomas More brought together the thoughts of philosophers of the past, for whom a harmonious world was a union of people and gods.

In the article «Notes on Utopia, the City, and Architecture», Antoine Picon, the professor of the history of architecture and technology, examined the question of how urban and architectural projects were presented by utopian thinkers. Antoine Picon writes that utopia, 
urbanism, and architecture are intertwined, creating many possible scenarios [4]. It was the city that was the space for transformations. During the Renaissance, many projects of ideal cities were created. In the $18^{\text {th }}$ century, architectural utopias were developed while being closely connected to social processes. The ideal urban structure, according to its authors, is based on ideal architectural forms. The utopianists were convinced that the creation of an ideal world would be impossible without a change. Many projects of perfect utopian cities were created to remain on paper, unrealized; such projects received a name «visionary architecture». These fantasy worlds were unfeasible because of technical restrictions of the time or because they contradicted the political views of the state. In the $19^{\text {th }}$ century, utopia took on the effect of reality and detail; new concepts of ideal cities are based on facts and scientific objectivity. There were less and less unexplored places left on the map of the world, less and less places to idealize the unexplored. Robert Owen and Charles Fourier, the creators of ideal cities, presented the concepts of small low-rise settlements. In 1833, Chicago appeared on the map. The city was based on the grid plan, and its first skyscraper was built in 1885. In 1898, Ebenezer Howard introduced «Garden Cities» which references Plato's utopian planning of Atlantis.

At the beginning of the $20^{\text {th }}$ century, the world faced various cataclysms. Hoping that architecture can bring salvation, the architects were developing new cities in the spirit of utopian ideals. Some were based on the development of technology, some - on the development of new lands, and others were meant to solve social issues. Antonio Sant'Elia presented the futuristic concept of «La Città Nuova», which was heavily based on the use of vertical dimension. It included such innovative elements as skyscrapers, bridges, and cable cars.

Le Corbusier believed that with the rational planning of the city, it was possible to solve social issues by reduing the time spent on reaching the destination - e.g., shortening the period of construction could lead to the industrialization of housing [4]. He argued that it is vital to modernize the construction process, stepping forward from outdated methods. Le Corbusier created experimental utopian concepts with his own vision of ideal cities: «Plan Voisin», an idea for a city center with vertical construction plan and green gardens; «Ville Radieuse» - a plan that lacked the human scale and the elements of nature and which became an inspiration for many cities.

Le Corbusier actively developed the principles of urban planning and mass housing construction. His utopian thoughts contain the idea that there should be no mixing of different functions in the city. One day, the plan of the city of Chandigarh was brought to life, where «Utopia» was adapted to the context of the area [5]. In 1932, in his concept of «Broadacre City», Frank Lloyd Wright described an idea of an aerator, an unmanned transport accessible for every family. Numerous futuristic concepts perfectly reflect the view of utopia impeccable worlds with innovative ideas of life within different elements - under or on the ground, under the water, in the air, and in space. Utopia was a mean of self-expression, where many of the ideas included a wide variety of «vertical cities» of the future.

In the $21^{\text {st }}$ century, utopia is the discovery of new possibilities in the present. Indeed, all the concepts of the future that architects and researchers envision seem to be utopian: automated cities, aerial streets for self-piloting transport, waste-free construction. Utopian projects shape our view for the future; create the contours of space and plot lines.

Practical experience and regulatory documents impose restrictions and adjustments when detailing the space [6].

In the course of the research, the method of comparative analysis of architectural projects of the future high-rise buildings was used. The idealization method is used to derive the hypothesis for vertical cities.

The examples of utopia on the verge of reality, innovative projects of foreign architects created over the past few years are presented in Table. 
Table. Future city projects.

\begin{tabular}{|c|c|c|c|}
\hline The main information & city or skyscraper & architectural design & planning structure \\
\hline $\begin{array}{l}\text { 1.Vertical city } \\
\text { Luca Curci architects } \\
2019\end{array}$ & $\begin{array}{l}\text { vertical city } \\
\text { in a new } \\
\text { territory }\end{array}$ & $\begin{array}{l}\text { streamlined } \\
\text { fractal structure of } \\
\text { the facade }\end{array}$ & $\square$ living space \\
\hline $\begin{array}{l}\text { 2.Post-pandemic city of } \\
\text { tomorrow } \\
\mathrm{O} 2 \text { design atelier } \\
2020\end{array}$ & $\begin{array}{l}\text { vertical city } \\
\text { in a new } \\
\text { territory }\end{array}$ & $\begin{array}{l}\text { object from simple } \\
\text { universal forms }\end{array}$ & $\begin{array}{l}\text { living space } \\
\end{array}$ \\
\hline $\begin{array}{l}\text { 3.Epidemic Babel } \\
\text { D Lee, Gavin Shen, } \\
\text { Weiyuan Xu, Xinhao } \\
\text { Yuan } \\
2020\end{array}$ & 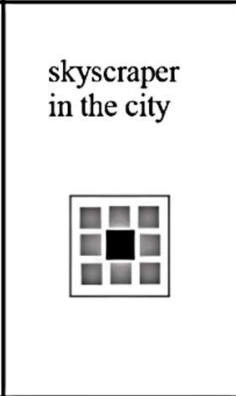 & modular connection & living space \\
\hline $\begin{array}{l}\text { 4.The Link } \\
\text { Luca Curci architects } \\
2020\end{array}$ & $\begin{array}{l}\text { vertical city } \\
\text { in a new } \\
\text { territory }\end{array}$ & $\begin{array}{l}\text { cone-shaped } \\
\text { streamlined }\end{array}$ & living space \\
\hline $\begin{array}{l}\text { 5.Metallic Villadrone } \\
\text { Studio MK27 } \\
2020 \\
\\
\\
\end{array}$ & $\begin{array}{l}\text { skyscraper } \\
\text { in the city } \\
\text { or } \\
\text { vertical city } \\
\text { in a new } \\
\text { territory } \\
\square\end{array}$ & $\begin{array}{l}\text { cone-shaped } \\
\text { streamlined }\end{array}$ & $\begin{array}{l}\text { parking space } \\
+ \\
\text { mobile capsule }\end{array}$ \\
\hline
\end{tabular}


The projects are considered as residential units of a vertical city. The comparison of objects is based on the following criteria: the placement of objects in an urban environment, their shape, and planning structure.

1. The placement of the objects in an urban environment: objects in an urban environment can consist either of separate units in an existing structure, or they can be formed by several objects and creating the structure of a vertical city.

For the sustainable growth of the cities, a development of the scenarios of response to various disasters and pandemics is required [7].

2. The structure is based on simple streamlined shapes. The wind resistance of the structure, the dependence of the wind load on the air density, the energy consumption of buildings should be taken into consideration for creating an energy-efficient form for the optimal density of a sustainable city $[12,19]$. It is worth noting that the construction of the future will rely on the emergence of new materials and technologies for waste-free production [16]. For example, «Epidemic Babel» is a project of a medical skyscraper designed to quickly respond to pandemics by assembling the object's framework.

Architecture is a way of visual consumption. The architecture of high-rise buildings is defined by the internal framework of the building and its functionality, and it is also important for it to reflect the identity of its surrounding area [8,14]. The architectural image of the objects «Verticality» and «Epidemic Babel» is created by the modular structural network of the facade.

3. Planning structure. The internal spaces of the planning structure should allow functional flexibility for a quick adaptation to changing circumstances.

The aesthetic appearance and mobility of the building's planning are connected to the creation of unique facade and shape $[9,11]$. The project «Metallic Villadrone» imagines a city in 2100 with flying multifunctional capsules serving as living units. Conservation of nature with the help of concise planning solutions is presented by «Post-Pandemic City of Tomorrow» and «The Link» as a response to the environmental problems.

\section{Results}

The analysis of volume-planning and the architectural features of vertical construction revealed a number of trends in the projects created in recent years.

- Sustainable urbanism is an integral part in creating future paradigms of vertical cities [1].

The importance of strategic planning of high-rise construction is determined by the planning structure, the population density of the city, functional diversity, transport structures, and landscaping.

- The height of the existing skyscrapers and the innovative technologies used during their creation are outstanding. It is important to develop the optimal height for future vertical cities, whether there will be dominants or all objects will have the same number of floors. The height of the building is related to the population density. A vertical city is not a single building, but a system of high-rise structures. Architecture and its visual perception is one of the key aspects of human existence in vertical cities. Human scale is an important factor for consideration while creating lower floors in high-rise buildings.

- The formation and the planning structure of high-rise construction should be adapted to its aerodynamic needs. Vertical cities involve innovative technologies, renewable energy sources, and water-saving systems.

In high-rise buildings, the area of the facade allows for the use of solar energy and the integration of photovoltaic systems [17].

- Functional content of the building. It is important to create the paths for the development of a future vertical city and take into account many influence factors [22].

A high-rise building may be monofunctional: it can consist of a residential area with public spaces, while the first floors are used by commercial entities. The visual appearance 
of the building affects the functional features of the space, and may also bring to life the concept of a «vertical street».

- Healthy environment. The presence of landscaping is important for the surrounding areas of vertical complexes. These requirements may be attained by the use of facade landscaping and green public spaces.

Such «oases» in residential buildings satisfy the social functions by supporting mental health and reduce the level of stress [21]. It is planned that landscaping should be implemented in $30-50 \%$ of the densely populated areas of vertical cities [20]. Green spaces need to be organically intertwined with the structure of the building. Healthy cities should take into account the consequences of COVID-19 while adapting the spaces.

- Transport and communication framework. The basis of the urban structure is streets, pedestrian accessibility and transport infrastructure, which are wide enough for the movement of pedestrians and vehicles, including those specialized for vertical communications. A well-developed pedestrian network involves not only streets, but also bridges, and reduces the time spent to reach a destination. It is important to analyze the jobs and ways of employment of the future and allow the possibility of a mass switch to remote work. It is impossible to know whether modern cities will use the systems we imagine. Perhaps, the city development indeed will go in a vertical direction, «improving» and adapting modern skyscrapers and designing vertical streets. With possible appearance of accessible unmanned vehicles leading to the new ways of parking, the new limits of the building heights will become an important question to consider. A residential unit may become a flying object which can change its position in the frame of a high-rise building.

- A high-quality urban environment creates a solution of a seamless coexistence of the present buildings and those of the future. Vertical complexes should be integrated into context of the area.

A well-organized use of vertical spaces inside and outside of the buildings will allow humanity to live in a comfortable environment. The main components of the architecture of the future are safety and adaptability, equality and acceleration of the development of new construction trends.

The increase in population density on the planet and the shortage of land, ecological issues and climate change are determining numerous concepts for the vertical cities of the future. It is important to consider the changes that will take place in the environment and how will the future cities respond to such changes. The world is already in a transition between the past and the future, when the trends of high-rise construction are establishing and evolving. As the cities in developed countries are becoming more densely populated, they begin to actively develop their high-rise architecture.

Pandemic and the fight against it became one of the main challenges of the $21^{\text {st }}$ century. There is a need for cities that provide safety from virus and infectious outbreaks [2]. The ability to separate human flows and allow safe social isolation with an easy access to health services are the important aspects that should be taken into consideration when designing a city.

The trend of developed cities will be a horizontal expansion with an active development of vertical dominants [3]. It can be assumed that the first vertical city is expected to appear in one of the developed countries in the $21^{\text {st }}$ century. While such projects have been designed by foreign architects for many years, the limits of economic efficiency, structural components, climate or lacking innovative solutions create some difficulties for the development. The first country to build a vertical city will do so due to the problem of land shortage or overpopulation, with the innovative breakthrough being the reaction to the problems.

A Russian vertical city will remain a utopia for as long as there are enough land resources for the horizontal development of the cities. There is a surplus in the information sphere and architecture resulting in a trend towards clean facades and simple forms. Russia is a developed country with a range of high-rise architecture including residential buildings; the 
project of a Russian vertical city as a separate complex is a utopian project aimed at improving everyday life. However, an in-depth research and analysis of the economic efficiency of the object is needed with the understanding of how the climatic features of the country and the terrain will affect the structure of the object.

As a result, the projects will combine a high-sustainability model for a densely populated area aimed at creating a hybrid city with zero energy consumption and interconnected spaces.

\section{Discussion}

The study examines the tendencies of the utopia ideas of architects, urban planners and philosophers since ancient times. Concepts were transformed and filled with idealistic ideas, solving the problems of their time. In the future, they took on specific outlines in the heads of subsequent generations. Some of the ideas have been successfully implemented, but history has made its own adjustments.

After studying the theoretical base, there was a demand for a comparative analysis of modern high-rise buildings and in determining the general trends in construction. Analysis of space-planning and architectural solutions helped to formulate the main directions in the development of a vertical city through projects in recent years. The hypothesis showed a possible vector of thoughts about what would contribute to the construction of a separate vertical city.

The significance of the topic based on the fact that the concepts of vertical cities are aimed at improving the quality of the space around us. The architecture is characterized by continuity from the surrounding world. Factors such as human behavior and emotions, sociocultural interactions, and consumption economics influence the formation of the urban environment.

Problems environmental disasters do not occur for no reason; the earth needs to be liberated. This is a catalyst in the development of vertical cities; new approaches appear in the formation and constructive component of objects.

\section{Conclusion}

1. The study shows that since ancient times, humanity has been drawn to the sky, and upward movement in architecture is inevitable. The concept of a vertical city is not a utopia and a beautiful picture, but a compilation of real processes for a better life, which humanity can only organize by joint efforts. However, only time will tell whether the architects' ideas are utopian or realistic.

Human-environmental interactions should not be swallowed up by technocentricity. It is important that the city remains empathic and the person remains a priority [13].

2. A sustainable and healthy vertical city is a city that improves the environment and social environment, complements all life functions, is safe, and uses modern technologies to control the quality of space $[10,15]$.

It is important to note that the identified criteria for the architectural space of vertical cities will allow humanity to live in a comfortable environment, even during the period of forced critical conditions and cataclysms.

3. The following trends are highlighted in the development of vertical construction:

- sustainable urbanism;

- optimal altitude for a given location;

- dependence of shape and planning on external influences;

- the correct calculation of the frame and the use of innovative technologies [18];

- functional filling of the building with everything that is necessary for the human life cycle; 
- high-quality urban environment for all population groups and ages, including for people with limited mobility;

- modernized transport and communication framework.

4. The results of this work can be used to predict the processes of urbanization and deurbanization in the world. The use of materials from this study will help in developing a concept for the development of a sustainable model of the future vertical city.

For further work, it is necessary to study the trends of modern building technologies, to develop optimal volume-planning models of vertical cities. Investigate in detail the ecological and psychological aspects of such structures on humans and the environment.

\section{References}

1. S.E. Bibri, J. Krogstie, M. Kärrholm. Compact city planning and development: Emerging practices and strategies for achieving the goals of sustainability, Developments in the Built Environment 4, (2020). DOI: 10.1016/j.dibe.2020.100021.

2. N.A. Megahed, E.M. Ghoneim. Antivirus-built environment: Lessons learned from Covid-19 pandemic, Sustainable Cities and Society 61, (2020). DOI: 10.1016/j.scs.2020.102350.

3. R. Jedwab, P. Loungani, A. Yezer. Comparing cities in developed and developing countries: Population, land area, building height and crowding, Regional Science and Urban Economics 86, (2021). DOI: 10.1016/j.regsciurbeco.2020.103609.

4. A. Picon. Notes on Utopia, the City, and Architecture, Grey Room 68, 94-105 (2017). DOI: 10.1162/GREY_a_00222.

5. L. Mora, M. Deakin. Untangling Smart Cities 118, 1-9 (2019). DOI:10.1016/B978-0-12815477-9.00001-3.

6. L. Anthopoulos. Smart utopia VS smart reality: Learning by experience from 10 smart city cases 63, 128-148 (2017). DOI: 10.1016/j.cities.2016.10.005.

7. R.A. McManamay, C.R. DeRolph, S. Surendran-Nair, M. Allen-Dumasb. Spatially explicit land-energy-water future scenarios for cities, Guiding infrastructure transitions for urban sustainability 112, 880-900 (2019). DOI: 10.1016/j.rser.2019.06.011.

8. E.E. Iusupova, Z.M. Aglyamova, S.G. Korotkova. Creating conceptual model of a multifunctional residential building based on sustainable design methods, Izvestiya KGASU 2 (48), 108-115 (2019).

9. S. Ritter De Paris, C. Nuno, L. Lopes. Housing flexibility problem: Review of recent limitations and solutions, Frontiers of Architectural Research 7, 80-91 (2018). DOI: 10.1016/j.foar.2017.11.004.

10. D.M. Risdiana, T.D. Susanto. The Safe City: Conceptual Model Development - A Systematic Literature Review, Procedia Computer Science 161, 291-299 (2019). DOI: 10.1016/j.procs.2019.11.126.

11. A.R. Minabutdinova, I.N. Agisheva. Principles of forming a transformable living space, Izvestiya KGASU, 3 (49), 62-70 (2019).

12. E. Ahmadian, B. Sodagar, C. Bingham, A. Elnokaly, G. Mills. Effect of urban built form and density on building energy performance in temperate climates, Energy and Buildings 236, (2021). DOI: 10.1016/j.enbuild.2021.110762.

13. N. Biloria. From smart to empathic cities, Frontiers of Architectural Research 10, 3-16 (2021). DOI: 10.1016/j.foar.2020.10.001.

14. M. Mihaila. City Architecture as Cultural Ingredient, Procedia - Social and Behavioral Sciences 149, 565-569 (2014). DOI: 10.1016/j.sbspro.2014.08.211.

15. M. Crane, S. Lloyd, A. Haines, D. Ding, Emma Hutchinson, K. Belesova, M. Davies, D. Osrin, N. Zimmermann, A. Capon, P. Wilkinson, C. Turcue. Transforming cities for 
sustainability: A health perspective, Environment International 147, (2021). DOI: 10.1016/j.envint.2020.106366.

16. J.E. Abaya Gomez Jr. The size of cities: A synthesis of multi-disciplinary perspectives on the global megalopolis, Progress in Planning 116, 1-29 (2017). DOI: 10.1016/j.progress.2016.03.001.

17. S. Freitas, M.C. Brito. Solar façades for future cities, Renewable Energy Focus 31, 73-79 (2019). DOI: 10.1016/j.ref.2019.09.002.

18. J. Auerbach, P. Wan. Forecasting the urban skyline with extreme value theory, International Journal of Forecasting 36, 814-828 (2020). DOI: 10.1016/j.ijforecast. 2019.09.004

19. Y.C. He, H.B. Lin, J.Y. Fu, P.W. Chan, Q.X. Zheng, T. Deng. Dependence of wind load on air density for highrise buildings, Journal of Wind Engineering and Industrial Aerodynamics 211, (2021). DOI: 10.1016/j.jweia.2021.104558.

20. T.E. Morakinyo, A. Lai, K. Ka-Lun Lau, E. Ng. Thermal benefits of vertical greening in a high-density city, Case study of Hong Kong, Urban Forestry \& Urban Greening 37, 42-55 (2019). DOI: 10.1016/j.ufug.2017.11.010.

21. M. Elsadekab, B. Liu, Z. Lian. Green façades: Their contribution to stress recovery and well-being in high-density cities, Urban Forestry \& Urban Greening 46, (2019). DOI: 10.1016/j.ufug.2019.126446.

22. S. Toivonen, A. Rashidfarokhi, R. Kyrö. Empowering upcoming city developers with futures literacy, Futures 129, (2021). DOI: 10.1016/j.futures.2021.102734. 